\title{
Group B Streptococcus serotypes III and V induce apoptosis and necrosis of human epithelial A549 cells
}

\author{
ANDRÉIA FERREIRA EDUARDO DA COSTA ${ }^{1}$, CAMILA SERVA PEREIRA $^{1}$, GABRIELA DA SILVA SANTOS ${ }^{1}$, \\ TÉCIA MARIA ULISSES CARVALHO ${ }^{2}$, RAPHAEL HIRATA $\mathrm{Jr}^{3}$, ANA LUIZA DE MATTOS-GUARALDI ${ }^{3}$, \\ ANA CLÁUDIA DE PAULA ROSA ${ }^{3}$ and PRESCILLA EMY NAGAO ${ }^{1}$ \\ ${ }^{1}$ Departamento de Biologia Celular, Instituto de Biologia Roberto Alcântara Gomes, Universidade do Estado \\ do Rio de Janeiro; ${ }^{2}$ Laboratório de Ultraestrutura Celular Hertha Meyer, Instituto de Biofísica Carlos \\ Chagas Filho, Universidade Federal do Rio de Janeiro; ${ }^{3}$ Disciplina de Microbiologia e Imunologia, \\ Faculdade de Ciências Médicas, Universidade do Estado do Rio de Janeiro, Rio de Janeiro, Brazil
}

Received December 7, 2010; Accepted January 21, 2011

DOI: 10.3892/ijmm.2011.635

\begin{abstract}
Although group B Streptococcus (GBS) has been classically described as an exclusively extracellular pathogen, growing evidence suggests that it may be internalized by epithelial cells. However, the fates of intracellular GBS and of infected respiratory epithelial cells remain unclear. Little is known about the bacterial components involved in these processes. The present study investigated the bacterial internalization by A549 cells and the apoptosis/necrosis of the infected human epithelial cells. The morphological changes in A549 cells observed from 2 h post-infection with GBS included vacuolization and the formation of apoptotic bodies. Flow cytometry revealed that $81.2 \%$ of apoptotic A549 cells were infected with GBS serotype III 90356-liquor. Moreover, a double-staining assay using propidium iodide (PI)/Annexin V (AV) gave information about the numbers of viable $\left(\mathrm{PI}^{-} / \mathrm{AV}^{-}\right)(18.27 \%)$ vs. early apoptotic $\left(\mathrm{PI}^{-} / \mathrm{AV}^{+}\right)$ $(73.83 \%)$ and late apoptotic cells $\left(\mathrm{PI}^{+} / \mathrm{AV}^{+}\right)(7.37 \%)$ during infection of A549 cells with GBS III 90356-liquor. In addition, 37\% necrotic cells were observed in A549 cells infected with GBS serotype V 90186-blood. In conclusion, GBS serotypes III and V induce apoptosis of epithelial cells in the early stages of GBS infection, resulting in tissue destruction, bacterial spreading and, in consequence, invasive disease or systemic infection.
\end{abstract}

Correspondence to: Dr Prescilla Emy Nagao, Departamento de Biologia Celular, Instituto de Biologia Roberto Alcântara Gomes, Universidade do Estado do Rio de Janeiro, R. São Francisco Xavier, 524-PHLC, $5^{\circ}$ andar, sala 501B, Maracanã, Rio de Janeiro, RJ 20.550-013, Brazil

E-mail: pnagao@pq.cnpq.br

Key words: group B Streptococcus, cellular interaction, apoptosis, necrosis, A549 cells

\section{Introduction}

Group B Streptococcus (GBS; Streptococcus agalactiae) is the leading cause of neonatal bacterial invasive diseases (1). The organism colonizes the vagina, rectum and urethra of 10-35\% of adults without causing disease. Neonates acquire GBS either in utero or during birth, aspirating GBS-containing fluid. GBS enters the lungs, binds to and invades the alveolar epithelial cells, and enters the blood, allowing the organisms to infect multiple organs. Invasive disease occurs within hours of birth, with 4-6\% mortality (2).

GBS has also been shown to be pathogenic in the elderly and in adults with underlying medical conditions, including diabetes (3). The rate of invasive diseases is significantly higher in neonates than in adults. However, the case fatality rates are greater in adults (4), with the incidence of GBS disease increasing with advanced age (5). Despite the clinical importance of these diseases, little is known about the events that lead up to GBS invasion and its virulence factors.

GBS invasion of alveolar epithelial cells and pulmonary endothelial cells has been clearly demonstrated in human tissue culture lines and in the primate model of early-onset infection $(6,7)$. However, the molecular mechanisms underlying the damage to the epithelial cells are largely unresolved.

Airway epithelial cells play a critical role in orchestrating both innate defense and inflammatory responses; these cells have been recognized as primary elements generating signals to activate other cells in the lung (8). Some studies suggest that internalization of bacteria by airway epithelial cells, followed by apoptosis of infected cells, is essential for the clearance of bacteria from the lungs, as apoptotic cells are shed and phagocytized by neutrophils (9). In addition, bacterial internalization can lead to the release of some pathogen-associated molecules activating innate recognition receptors and consequently inducing innate immune responses (10).

Apoptosis and necrosis constitute the principal mechanisms by which programmed host cell death occurs. Each cell death mode is characterized by particular morphological changes and distinctive molecular signaling pathways. Therefore, in 
this work we examined the adherence, internalization, intracellular survival and cellular death caused by GBS serotypes III and V strains in human type II alveolar epithelial cells (A549 cells) in the context of microbial infection.

\section{Materials and methods}

Bacterial strains. GBS serotype III (strains 80340-vagina and 90356-liquor) and serotype V (strains 88641-vagina and 90186-blood), were used in this study and were partially investigated for their adhesive properties (11). The strains were identified as group B and serotyped as previously described (12). The microorganisms were stored after lyophilization and recovered in Brain Heart Infusion broth (BHI; Difco Laboratories Inc, Detroit, MI, USA). GBS isolates were cultured on Blood agar base (BAB; Oxoid, Cambridge, UK) plates containing $5 \%$ sheep defibrinated blood (BAB/blood) for $24 \mathrm{~h}$ at $37^{\circ} \mathrm{C}$ and then grown in $\mathrm{BHI}$ at $37^{\circ} \mathrm{C}$ until a $0.4 \mathrm{OD}$ reading $\left(\sim 10^{8} \mathrm{CFU} / \mathrm{ml}\right)$ was reached $(11)$.

Lung epithelial cell culture. A549 cells (CCL-185, American Type Culture Collection, MD, USA), a human type II alveolar epithelial carcinoma cell line, were cultured and maintained in Dulbecco's modified Eagle's medium (DMEM; Sigma Chemical Co., MO, USA) supplemented with $10 \%$ fetal calf serum (FCS; Gibco-BRL, USA) and antibiotics. Monolayers were seeded in 24-well tissue culture plates (Corning) and were used experimentally within $24 \mathrm{~h}$ of establishing confluence.

Adherence and internalization assays. Confluent A549 cells

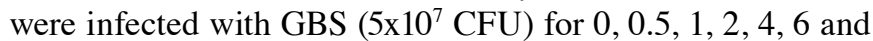
$8 \mathrm{~h}$ in $5 \% \mathrm{CO}_{2}$ at $37^{\circ} \mathrm{C}$. After each incubation period, infected cells were rinsed three times with DMEM, and then lysed in a solution of $0.5 \mathrm{ml}$ of $25 \mathrm{mM}$ Tris, $5 \mathrm{mM}$ EDTA, $150 \mathrm{mM}$ $\mathrm{NaCl}$ plus $1 \%$ Igepal (lysis buffer). Total GBS association (intracellular plus surface adherent) was estimated by plating epithelial lysates and counting the resulting colonies that appeared in BAB plates containing 5\% sheep defibrinated blood (BAB/blood medium). In order to measure bacterial internalization, a similar assay used for measuring adherence was performed. After each period of incubation, infected monolayers were incubated for an additional $2 \mathrm{~h}$ period in DMEM containing bactericidal amounts of both gentamicin $(100 \mu \mathrm{g} / \mathrm{ml})$ and penicillin $\mathrm{G}(5 \mu \mathrm{g} / \mathrm{ml})$. The number of internalized bacteria was determined as outlined above. The adherence rates were determined as follows: [CFU of total cell-associated (intracellular viable plus surface adherent) GBS-CFU intracellular GBS] (11).

Intracellular survival of GBS strains. Monolayers infected with the GBS strains were incubated in DMEM for $4 \mathrm{~h}$. The medium was then removed and the monolayers were incubated with DMEM containing penicillin $(5 \mu \mathrm{g} / \mathrm{ml})$ and gentamicin $(100 \mu \mathrm{g} / \mathrm{ml})$ for $2 \mathrm{~h}$ to kill extracellular bacteria. The infected monolayers were re-incubated for $0,0.5,1,2,4$, 18 and $24 \mathrm{~h}$ in $5 \% \mathrm{CO}_{2}$ at $37^{\circ} \mathrm{C}$. In order to count persistent bacteria of the intracellular compartment, the cells were washed with $\mathrm{NaCl} 0.9 \%$ and lysed with lysis buffer. The lysates were diluted and plated in $\mathrm{BAB} /$ blood medium for CFU counts (13).
Scanning electron microscopy (SEM). A549 monolayers infected with GBS for $4 \mathrm{~h}$ were incubated overnight at $4^{\circ} \mathrm{C}$ in a solution of $3 \%$ paraformaldehyde plus $2.5 \%$ glutaraldehyde in $0.1 \mathrm{M}$ cacodylate buffer. The resulting samples were washed and post-fixed in a solution of $1 \% \mathrm{OsO}_{4}$ plus $8 \mathrm{mM}$ potassium ferrocyanide and $10 \mathrm{mM} \mathrm{CaCl}_{2}$ in $0.1 \mathrm{M}$ cacodylate buffer. In the following step, both GBS infected and non-infected cells were dehydrated in a graded series of ethanol. All cells were dried to a critical point with $\mathrm{CO}_{2}$, and coated with a thin gold layer. The gold-coated samples were then observed in a Zeiss scanning electron microscope and a JEOL field emission scanner, operating at 15 and $10 \mathrm{kV}$, respectively (14).

Transmission electron microscopy (TEM). A549 cells were cultivated directly on plastic bottles and inoculated with $10^{8}$ $\mathrm{CFU} / \mathrm{ml}$ bacteria diluted in DMEM for $4 \mathrm{~h}$ at $37^{\circ} \mathrm{C}$. Following washes with $\mathrm{NaCl} 0.9 \%$, cells were fixed with $0.1 \mathrm{M}$ cacodylate buffer ( $\mathrm{pH} 7.2$ ) containing $2.5 \%$ glutaraldehyde, $4 \%$ paraformaldehyde, $0.1 \mathrm{M} \mathrm{CaCl}_{2}$ for $1 \mathrm{~h}$ at $4^{\circ} \mathrm{C}$. Monolayers were post-fixed with $2 \% \mathrm{OsO}_{4}, 5 \mathrm{mM} \mathrm{CaCl}_{2}$ and $0.8 \% \mathrm{~K}_{4}\left[\mathrm{Fe}\left(\mathrm{CN}_{6}\right)\right]$ in cacodylated buffer for $1 \mathrm{~h}$ at $22^{\circ} \mathrm{C}$, and dehydrated through a series of graded ethanol solutions and embedded in Epon 812 resin. Ultrathin sections were examined under a Zeiss EM 906 transmission electron microscope (Zeiss, Oberkochen, Germany) (15).

Analysis of A549 cells by flow cytometry for apoptosis and necrosis. For identification of apoptosis and necrosis of the A549 cells infected with GBS 90356-III or 90186-V during $12 \mathrm{~h}$ at $37^{\circ} \mathrm{C}$, the binding of Annexin $\mathrm{V}$ and the uptake of propidium iodide (PI) were measured by flow cytometry with a FACScan flow cytometer (Becton-Dickinson Immunocytometry Systems Europe, Erembodegem, Belgium) equipped with an air-cooled $15 \mathrm{~mW}$ argon-ion laser operating at $488 \mathrm{~nm}$. The standard filter configuration was used for data acquisition. The experiments were performed using the apoptosis and necrosis detection kit TACS Annexin V-FITC (R\&D Systems, Wiesbaden, Germany) according to the manufacturer's instructions. Flow cytometric analysis was performed using the Cell-Quest software program (Becton-Dickinson). Logarithmic fluorescence intensity of Annexin V-FITC was plotted vs. the fluorescence intensity of PI in a dot plot. Data from 10,000 epithelial cells were analyzed for each plot. The experiments were performed three times and results of a representative experiment are shown.

Statistical analysis. Results are expressed as means \pm SD of data obtained in at least three different experiments. Statistical differences between groups were determined with the unpaired Student's t test or one-way analysis of variance (ANOVA) followed by the Dunnett's or Tukey's multiple comparison tests. Statistical significance was set at $\mathrm{P}<0.05$.

\section{Results}

Adhesion and internalization of GBS strains to A549 cells. All GBS strains showed similar binding properties (Fig. 1). Most isolates showed higher adherence within $6 \mathrm{~h}$ of incubation (Fig. 1A and B). All GBS strains showed internalization during the first $4 \mathrm{~h}$ incubation (Fig. $1 \mathrm{C}$ and D). Except for the 

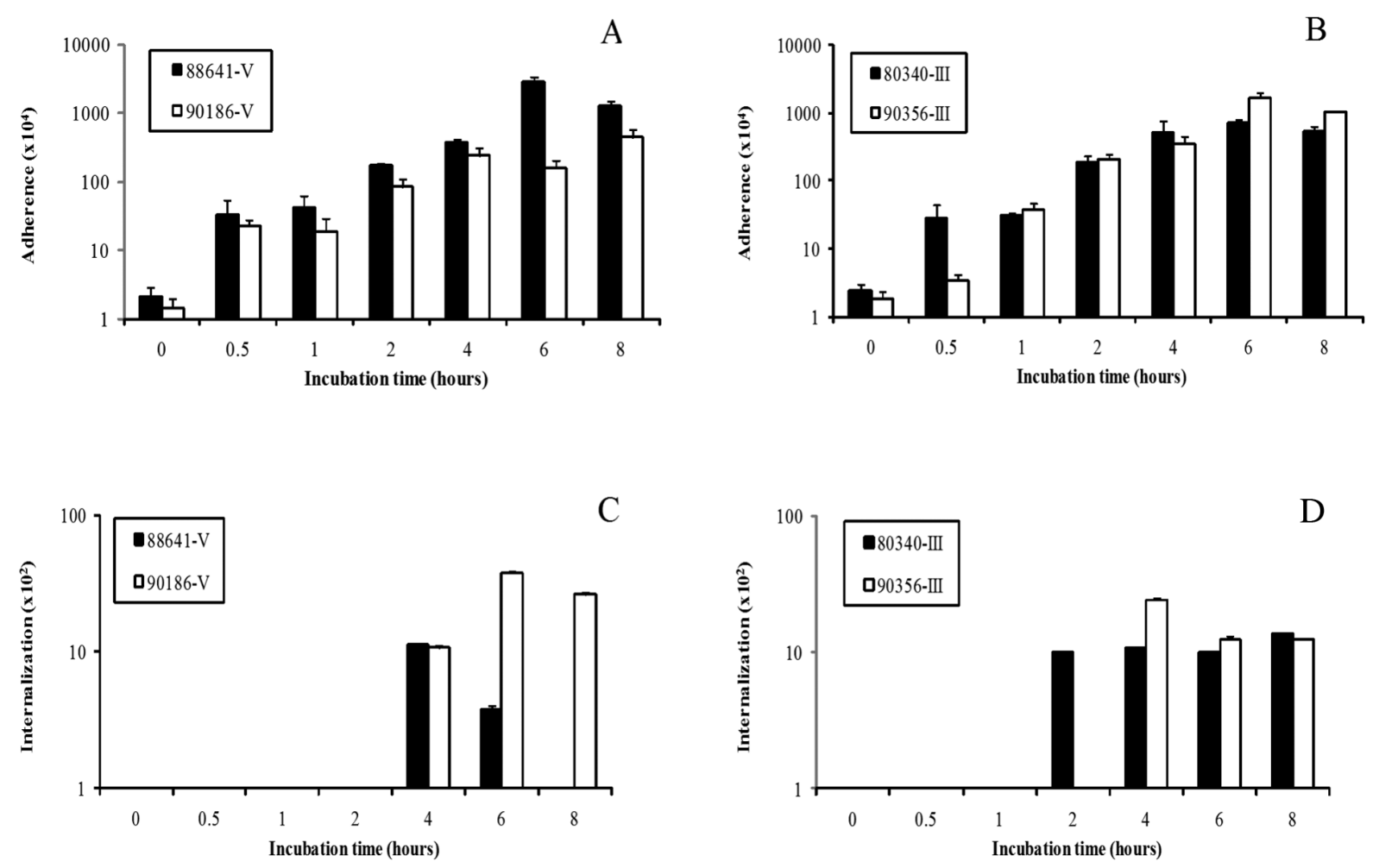

Figure 1. Adherence (A and B) and internalization (C and D) of GBS to A549 cells: GBS strains 88641 and 90186 serotype V (vagina and blood, respectively) and GBS strains 80340 and 90356 serotype III (vagina and liquor) were examined. Results are the means \pm standard deviations from at least three independent experiments in duplicate wells. Data are presented in a graphic log scale.

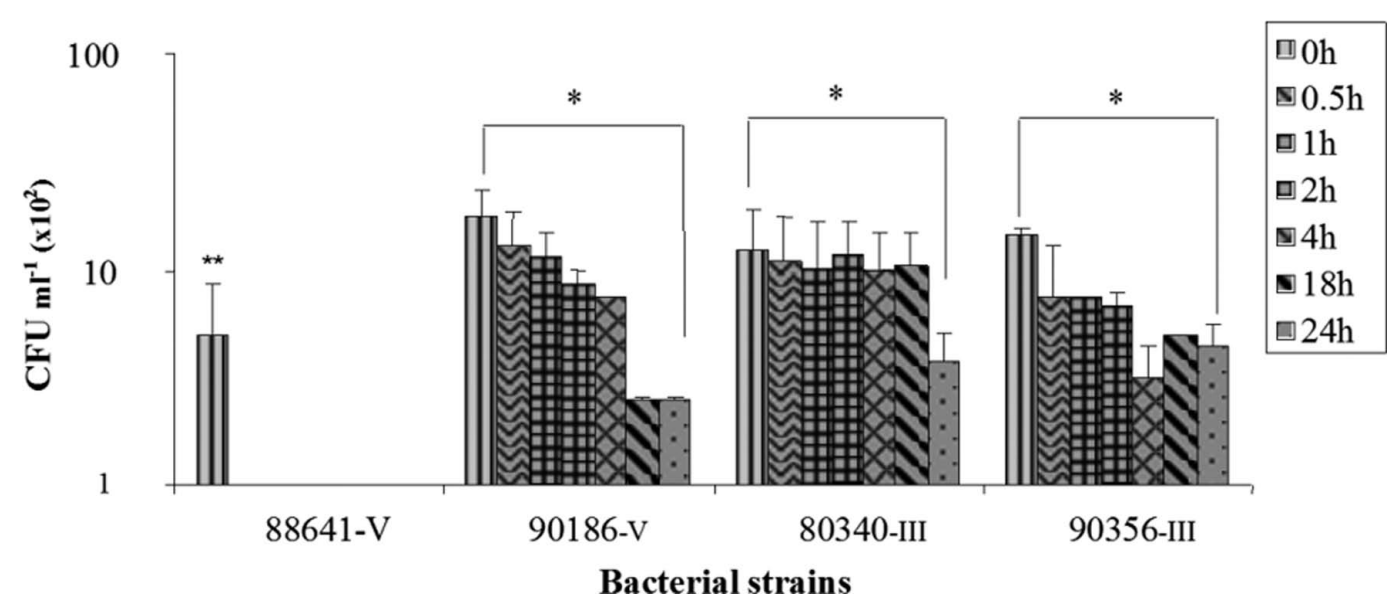

Figure 2. Intracellular survival of GBS strains into A549 cells after 0, 0.5, 1, 2, 4, 18 and $24 \mathrm{~h}$ of incubation. *Significant decrease in the number of GBS during incubation with A549 cells observed between 0 and $24 \mathrm{~h} .{ }^{* *}$ Significant decrease in the number of GBS during incubation with A549 cells observed between 0 and $0.5 \mathrm{~h}$ incubation. Results are the means \pm standard deviations from at least three independent experiments in duplicate wells. Data are presented in a graphic $\log$ scale.

88641-V strain that survived only for $6 \mathrm{~h}$ incubation, strains of all serotypes tested were found to survive $8 \mathrm{~h}$ into A549 cells $(\mathrm{P}<0.05)$. A fraction of the A549 cells, as examined by light microscopy, underwent pronounced vaccuolization after the interaction with GBS strains at all incubation times (data not shown). Approximately $60 \%$ of the cells were noticeably vacuolated and rounded at $2 \mathrm{~h}$. After $24 \mathrm{~h}, 100 \%$ of the A549 cells were vacuolated when associated with GBS. These findings suggest that the observed morphological changes are due to an association of GBS with the A549 cells or to a release of cellular components from these bacteria.
Intracellular survival of GBS strains into A549 cell. The kinetics of the survival of GBS within A549 cells without replication are shown in Fig. 2. Strains of serotypes III (80340 and 90356 strains) and V (90186 strain) remained viable within epithelial cells during $24 \mathrm{~h}$ incubation. However, the $88641-\mathrm{V}$ strain isolated from the vagina did not survive past $0.5 \mathrm{~h}$ of interaction.

Ultrastructural analysis of GBS interaction with A549 cell. Electron microscopy was used to examine the interaction of GBS with A549 cells. GBS cells were observed to be attached 

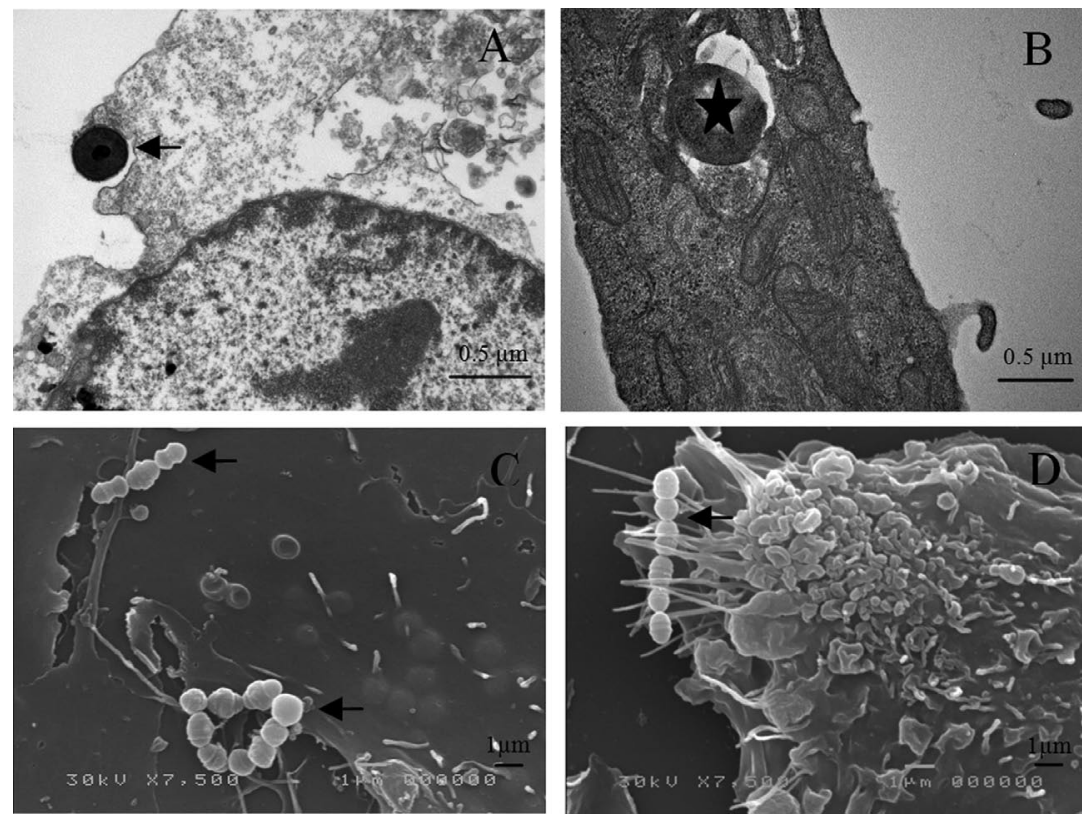

Figure 3. Electron micrograph of GBS adherence and invasion to A549 cells after $4 \mathrm{~h}$ of incubation. (A, C and D) GBS strain can be seen closely adhering on A549 cells surface (black arrows); (B) GBS closed in membrane-bound vacuoles on the intercellular space (star).

to the membranes of A549 cells, frequent intracellular localization of bacteria was also observed by TEM (Fig. 3A and B). By SEM, GBS strain can be seen closely adhering on A549 cells surface (Fig. 3C and D).

Flow cytometry. The results of experiments analyzed by flow cytometry that provide information about the numbers of viable $\left(\mathrm{PI}^{-} / \mathrm{AV}^{-}\right)$vs. apoptotic $\left(\mathrm{PI}^{-} / \mathrm{AV}^{+}\right)$cells and that concurrently provided the number of late apoptotic or secondary necrotic cells $\left(\mathrm{PI}^{+} / \mathrm{AV}^{+}\right)$are represented in Fig. 4. Compared to the untreated control cells, significant proportions of early $\left(\mathrm{PI}^{-} / \mathrm{AV}^{+} ; 73.83 \%\right)$ and late $\left(\mathrm{PI}^{+} / \mathrm{AV}^{+} ; 7.37 \%\right)$ apoptotic cells appeared when A549 cells were infected during $12 \mathrm{~h}$ with the GBS 90356-III strain (Fig. 4C). Interestingly, A549 cells infected with the 90186-V strain exhibited $35.12 \%\left(\mathrm{PI}^{+} / \mathrm{AV}^{-}\right)$ necrotic cells and a proportion of $1.14 \%$ of early $\left(\mathrm{PI}^{-} / \mathrm{AV}^{+}\right)$ and $8.29 \%\left(\mathrm{PI}^{+} / \mathrm{AV}^{+}\right)$seemed to represent late apoptotic cells that were binding AV and taking up PI (Fig. 4D). The total \% (early and late) of apoptotic cells corresponded to $81.2 \%$ and 9.43\% for A549 cells treated with GBS 90356-III or 90186-V, respectively. In contrast, the necrotic cells were observed to be $7.4 \%$ and $37 \%$ in A549 cells infected by GBS-III (strain 90356) or GBS-V (strain 90186), respectively (Fig. 4E and F).

\section{Discussion}

The ability of bacteria to adhere and invade host cells and their capability to induce apoptosis or necrosis suggest that these mechanisms may be considered as contributing factors in disease development by invasive microorganisms. Although evidence has suggested that GBS also invade epithelial cells (16), the fate of these cells after bacterial internalization is not known. In our study, we provided evidence that the GBS strains may induce apoptosis and necrosis in A549 cells.

In order to colonize a host, bacteria must display the ability to adhere to epithelial cells, which are an integral component of the mucosal immune system (17). Our results demonstrated that all isolates were able to adhere to A549 cells. The highest adhesion ability was observed for strain $88641-\mathrm{V}$ isolated from the vagina that did not survive within epithelial cells for over $6 \mathrm{~h}$ of incubation (Fig. 1C). Previous studies of these strains showed drastic differences in the expression of virulence factors $(18,19)$. These findings imply that the molecular interactions between these two serotypes of GBS can be significantly different. Interactions of GBS with epithelial cells resulting in adhesion and internalization are mediated by a number of bacterial products including pili, lipopolysaccharide, C5a peptidase, $\beta$-hemolysin and several host cell receptors, for example asialo GM1 and tolllike receptors that may contribute to the persistence of this infection in the lungs $(20,21)$. However, specific molecular mechanisms of GBS adhesion and internalization are still incompletely understood.

Townsend et al (22) have suggested that the ability to invade epithelial cells might be a strong indication of the potential virulence of GBS strains. We examined the interaction of GBS strains with A549 cells and demonstrated that one of the consequences of cell adhesion and invasion by the bacteria is injury to the epithelial cells and cell death. Using the annexin staining we observed that GBS III and V infection induced apoptosis and necrosis of the A549 cells, respectively. The highest apoptotic activity was expressed by GBS III 90356-liquor strains after $12 \mathrm{~h}$ incubation (73.83\%). Previous studies have shown that epithelial cells undergo apoptosis after adhesion or invasion by different pathogens. Enteropathogenic strains of Enterobacter sakazakii and Escherichia coli (EPEC) that revealed adhesion to epithelial cells induced apoptosis $(23,24)$. Species of several genera within the family Enterobacteriaceae, including Salmonella, Shigella and Yersinia have been found to trigger cell death of host epithelial cells after bacterial invasion (25). A number of microbial factors that can trigger the induction of apoptosis 
A

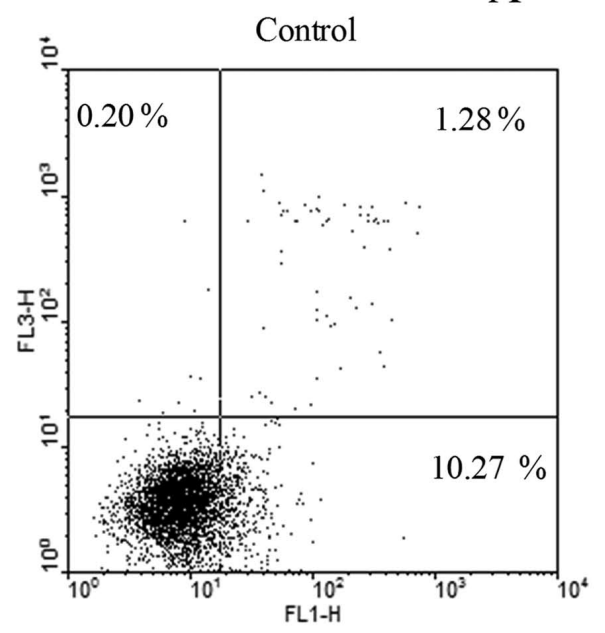

C

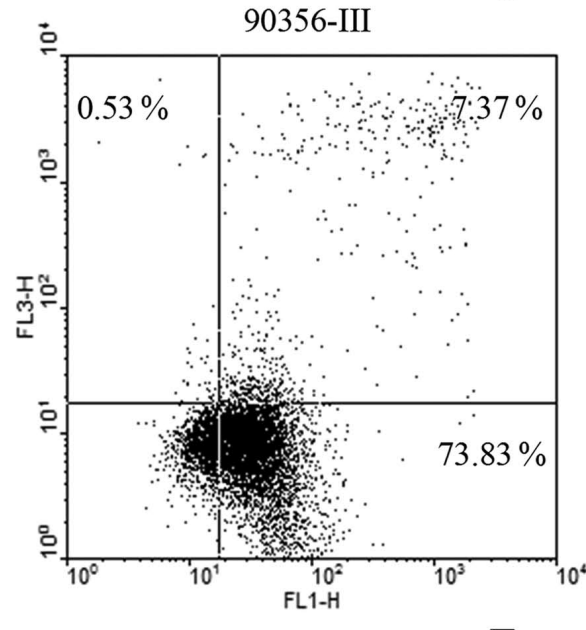

E

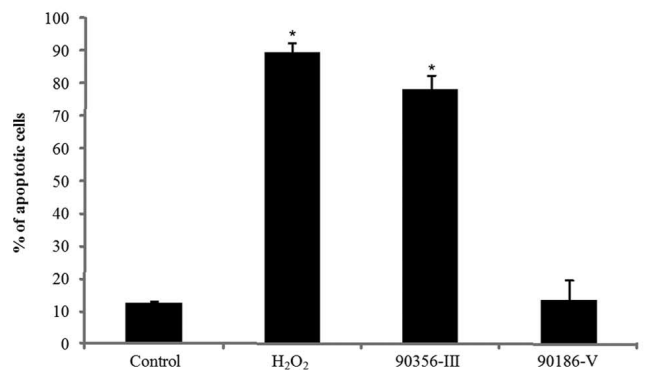

B

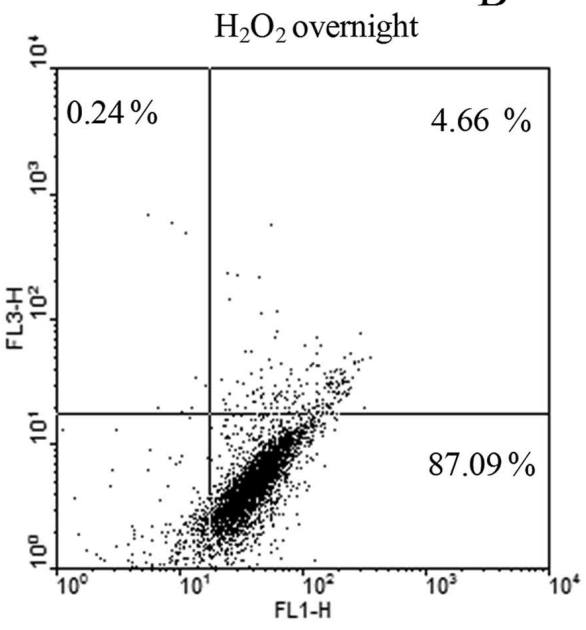

$\mathrm{D}$
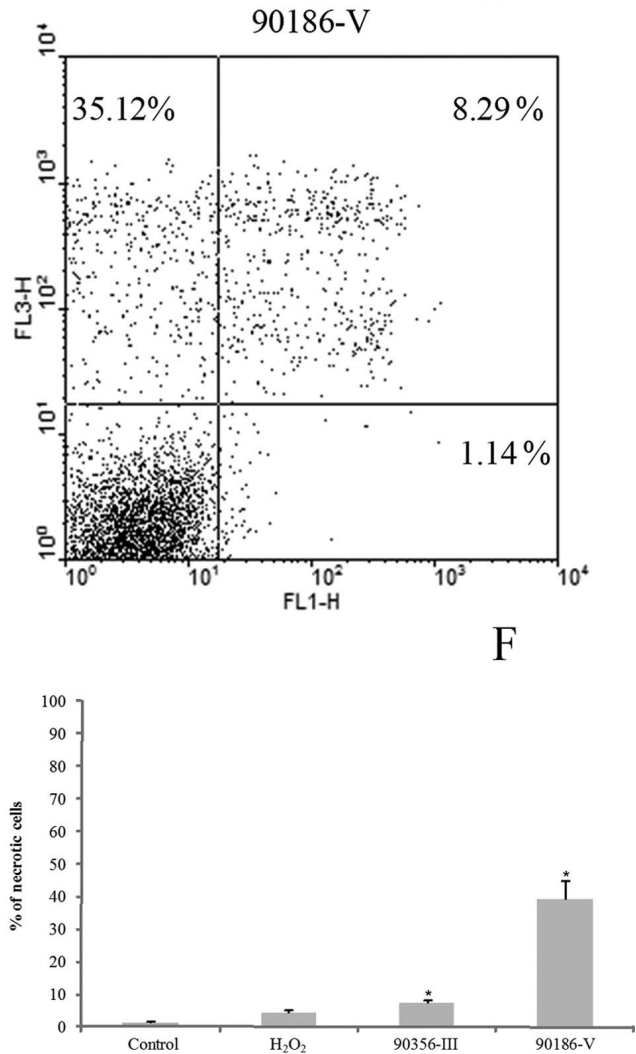

Figure 4. Flow cytometric analysis of phosphatidylserine externalization (Annexin V binding) and cell membrane integrity (PI staining) in A549 cells. The cells were infected with GBS serotypes III (90356-liquor) and V (90186-blood) for $12 \mathrm{~h}$. (A) control population; (B) A549 treated with $\mathrm{H}_{2} \mathrm{O}_{2}$ (positive control); (C) A549 cells infected with GBS 90356; (D) A549 cells infected with GBS 90186; (E) \% apoptotic cells from three independent experiments and (F) \% necrotic cells from three independent experiments. The dual parametric density plots combining Annexin V-FITC and PI fluorescence show the viable cell population in the lower left quadrant (Annexin $\mathrm{V}^{-} / \mathrm{PI}^{-}$), the early apoptotic cells in the lower right quadrant (Annexin $\mathrm{V}^{+} / \mathrm{PI}^{-}$), the late apoptotic cells in the upper right quadrant (Annexin $\left.\mathrm{V}^{+} / \mathrm{PI}^{+}\right)$, and the necrotic cells in the upper left quadrant (Annexin $\left.\mathrm{V}^{-} / \mathrm{PI}^{+}\right)$.

in host cells have been identified. Barnes et al (26) and Paraje et al (27) have isolated thiol-activated cytotoxic toxin from Enterobacter cloacae strains that exhibited hemolytic and leucotoxic effects. High concentration of the toxin generated reactive oxygen species, which led to oxidative stress and subsequent apoptotic cell death.

We observed that the interaction of GBS serotype V with epithelial cells led to necrotic damage. The highest necrotic activity was observed for GBS V isolated from the blood (37\%). Hunter et al (23) demonstrated that E. sakazakii induced clinical and histological necrosis in newborn rats. The strains were found to bind to enterocytes without direct invasion. They induced cell death and increased production of the inflammatory cytokine, IL-6.

GBS-induced disease is due to the severe inflammatory response of the infected tissue. This is characterized by the activation of transcription factors such as $\mathrm{NF}-\kappa \mathrm{B}$, resulting in the release of proinflammatory mediators, i.e. cytokines, TNF- $\alpha$, IL-1, IL-6, IL-8, recruitment of activated neutrophils, and severe tissue damage eventually leading to lung failure 
(28). The GBS strains are able to adhere to epithelial cells, become internalized, and induce apoptosis or necrosis of infected cells. These effects likely contribute to the efficient innate and adaptive immune responses, which help the host temporarily eradicate the infection during the period of intermittent colonization of the lung. Continuing stimulation of the host cells by proinflammatory mediators, along with escalating tissue damage, as well as developing resistance to many antibiotics, would eventually lead to exhaustion of host defense mechanisms. New strategies directed toward enhancing immune responses to GBS during the early stages of lung infection may prevent the establishment of the disease.

The results of this study lead to a better understanding of GBS infections and demonstrate that adhesion and invasion of the strains to epithelial cells induce apoptotic or necrotic cell death. Additional work is required to determine the substrates of GBS that are responsible for inducing necrosis and for further delineating the necrotic signaling cascades. These processes may be a primary strategy of the GBS strains, resulting in tissue destruction, bacterial spreading, and, in consequence, invasive disease or systemic infection.

\section{Acknowledgements}

The authors thank Mrs. Mariléa Temperine and Pamella da Silva Lannes for technical assistance. This study was supported by Conselho Nacional de Desenvolvimento Científico e Tecnológico (CNPq), Fundação de Amparo à Pesquisa do Estado do Rio de Janeiro (FAPERJ) and SR2/UERJ.

\section{References}

1. Arisoy AS, Altinisik B, Tunger O, Kurutepe S and Ispahi C: Maternal carriage and antimicrobial resistance profile of group B Streptococcus. Infection 31: 244-246, 2003.

2. Schrag SJ, Zywicki S, Farley M M, Reingold AL, Harrison LH, Lefkowitz LB, Hadler JL, Danila R, Cieslak PR and Schuchat A: Group B streptococcal disease in the era of intrapartum antibiotic prophylaxis. N Engl J Med 342: 15-20, 2000.

3. Tyrrell GJ, Senzilet LD, Spika JS, Kertesz DA, Alagaratnam M, Lovgren $M$ and Talbot JA: Invasive disease due to group B streptococcal infection in adults: results from a Canadian, population-based, active laboratory surveillance study - 1996 Sentinel Health Unit Surveillance System Site Coordinators. J Infect Dis 182: 168-173, 2000.

4. Schuchat A: Group B streptococcus. Lancet 353: 51-56, 1999.

5. Farley MM, Harvey RC, Stull T, Smith JD, Schuchat A Wenger JD and Stephens DS: A population-based assessment of invasive disease due to group B Streptococcus in nonpregnant adults. N Engl J Med 328: 1807-1811, 1993.

6. Rubens CE, Smith S, Hulse M, Chi EY and van Belle G: Respiratory epithelial cell invasion by group B streptococci. Infect Immun 60: 5157-5163, 1992.

7. Gibson RL, Lee MK, Soderland C, Chi EY and Rubens CE: Group B streptococci invade endothelial cells: type III capsular polysaccharide attenuates invasion. Infect Immun 61: 478-485, 1993.

8. Martin TR and Frevert CW: Innate immunity in the lungs. Proc Am Thorac Soc 2: 403-411, 2005.

9. Cannon CL, Kowalski MP, Stopak KS and Pier GB: Pseudomonas aeruginosa-induced apoptosis is defective in respiratory epithelial cells expressing mutant cystic fibrosis transmembrane conductance regulator. Am J Resp Cell Mol 29: 188-197, 2003.
10. Campodónico VL, Gadjeva M, Paradis-Bleau C, Uluer A and Pier GB: Airway epithelial control of Pseudomonas aeruginosa infection in cystic fibrosis. Trends Mol Med 14: 120-133, 2008.

11. Santos GS, Lione VO, Costa e Silva Filho F and Nagao PE: Signal transduction in human endothelial cells induced by their interaction with group B Streptococci. Int J Mol Med 15: 859-863, 2005.

12. Lancefield RC: A serological differentiation of specific types of bovine hemolytic Streptococci (group B). J Exp Med 59: 441-458, 1934.

13. Cornacchione P, Scaringi L, Fettucciari K, Rosati E, Sabatini R, Orefici G, von Hunolstein C, Modesti A, Modica A, Minelli F and Marconi P: Group B streptococci persist inside macrophages. Immunology 93: 86-95, 1998.

14. Santos GS, Loureiro Y Penha CV, Mattos-Guaraldi AL, Attias M, Lopes-Bezerra L, Silva-Filho FC and Nagao PE: Group B Streptococcus induces tyrosine phosphorylation of annexin $\mathrm{V}$ and glutathione S-transferase in human umbilical vein endothelial cells. Int J Mol Med 24: 393-399, 2009.

15. Teixeira CF, Azevedo NL, Carvalho TMU, Fuentes J and Nagao PE: Cytochemical study of Streptococcus agalactiae and macrophage interaction. Microsc Res Tech 54: 254-259, 2001.

16. Edwards MS and Baker CJ: Group B streptococcal infections. In: Infectious Diseases of the Fetus and Newborn Infant. 5th edition. Remington J and Klein JO (eds). WB Saunders, Philadelphia, pp1091-1156, 2001.

17. Niemann HH, Schubert WD and Heinz DW: Adhesins and invasins of pathogenic bacteria: a structural view. Microbes Infect 6: 101-112, 2004

18. São Jose AS, Miyazaki NHT, Hirata R Jr, Mattos-Guaraldi AL and Nagao PE: Intracellular viability in human non-polarized respiratory epithelial $16 \mathrm{HBE} 14 \mathrm{o}$ - cells by group B Streptococcus serotype III clinical isolates presenting $162-\mathrm{kb}$ and $183-\mathrm{kb}$ virulence markers. Int J Mol Med 17: 533-538, 2006.

19. Monteiro GC, Hirata R Jr, Andrade AF, Mattos-Guaraldi AL and Nagao PE: Surface carbohydrates as recognition determinants in non-opsonic interactions and intracellular viability of group B Streptococcus strains in murine macrophages. Int J Mol Med 13: 175-180, 2004.

20. Feldman RG, Rijkers GT, Hamel ME, David S and Zegers BJ: The group B streptococcal capsular carbohydrate: immune response and molecular mimicry. Adv Exp Med Biol 435: 261-269, 1998.

21. Rajagopal L: Understanding the regulation of Group B Streptococcal virulence factors. Future Microbiol 4: 201-221, 2009.

22. Townsend S, Hurrell E and Forsythe S: Virulence studies of Enterobacter sakazakii isolates associated with a neonatal intensive care unit outbreak. BMC Microbiol 8: 64-72, 2008.

23. Hunter CJ, Singamsetty VK, Chokshi NK, Boyle P, Camerini V and Grishin AV: Enterobacter sakazakii enhances epithelial cell injury by inducing apoptosis in a rat model of necrotizing enterocolitis. J Infect Dis 198: 586-593, 2008.

24. Abul-Milh M, Wu Y, Lau B, Lingwood CA and Foster DB Induction of epithelial cell death including apoptosis by enteropathogenic Escherichia coli expressing boundle-forming pili. Infect Immun 69: 7356-7364, 2001.

25. Gao LY and Kwaik YA: The modulation of host cell apoptosis by intracellular bacterial pathogens. Trends Microbiol 8: 306-313, 2000.

26. Barnes AI, Paraje MG, Battan PC and Albesa I: Molecular properties and metabolic effect on blood cells produced by a new toxin of Enterobacter cloacae. Cell Biol Toxicol 17: 409-418, 2001.

27. Paraje MG, Barnes AI and Albesa I: An Enterobacter cloacae toxin able to generate oxidative stress and to provoke dosedependent lysis of leucocytes. Int J Med Microbiol 295: 109-116, 2005.

28. Maisey HC, Doran KS and Nizet V: Recent advances in understanding the molecular basis of group B Streptococcus virulence. Expert Rev Mol Med 22: 10: e27, 2008. 